\title{
MENJAWAB DINAMIKA IMPLEMENTASI KURIKULUM 2013 DI SEKOLAH DASAR
}

\author{
Faisal \\ PGSD FIP UNIMED \\ Surel : faisalpendas@gmail.com
}

\begin{abstract}
ABSTRAK
Penelitian ini bertujuan untuk memperoleh informasi terkait dengan isuisu menonjol dalam implementasi kurikulum 2013 di SD. Isu-isu menonjol ini kemudian diolah dan diterjemahkan melalui studi literatur dan wawancara terhadap pihak yang berwenang sebagai upaya mencarikan solusi terhadap permasalahan yang ditemukan. Hasil temuan di SD Kab. Pasaman Barat menunjukkan bahwa terdapat empat isu menonjol yang ditemukan dalam implementasi kurikulum 2013 di SD, antara lain: (1) kebenaran Kompetensi Dasar (KD), mencakup: konsep/substansi, ruang lingkup (scope), urutan (sequence), penempatan pada Kompetensi Inti (KI), dan keterbacaan, (2) kedudukan pada Kompetensi Inti Spritual (KI-1) dan Kompetensi Inti Sosial (KI-2), (3) pembelajaran tematik terpadu SD/MI, dan (4) penilaian sikap. Empat isi menonjol inilah yang dikatakan dengan dinamika implementasi kurikulum 2013 di SD. Oleh sebab itu, perlu dicarikan solusi yang tepat dalam upaya menjawab dinamika implementasi kurikulum 2013 di SD, khususnya di SD Kab. Pasaman Barat.
\end{abstract}

Kata Kunci: Dinamika, Kurikulum 2013, SD

\section{PENDAHULUAN}

Akhir-akhir ini, kebijakan penerapan kurikulum 2013 menjadi isu penting dalam dunia pendidikan di Indonesia. Hal ini tidak hanya berlaku pada jenjang pendidikan dasar, namun juga berlaku pada pendidikan menengah (SMP/MTs dan SMA/MA/SMK). Perubahan mendasar yang cukup dirasakan terjadi pada pendidikan dasar, yaitu SD berupa perubahan struktur kurikulum, penerapan proses pembelajaran, hingga penilaian, baik pada aspek sikap, pengetahuan, maupun keterampilan. Struktur kurikulum semula yang dikatakan dengan kurikulum 2006 dirasakan belum mampu menciptakan proses pembelajaran yang mengondisikan pembentukan sikap, pengetahuan, dan keterampilan secara matang dan berimbang.
Kurikulum 2006 (KTSP) dikatakan dengan kurikulum berbasis kompetensi. Indikasi dikatakan dengan kurikulum berbasis kompetensi adalah terciptanya tiga ranah, yaitu pembentukan sikap, pengetahuan, dan keterampilan secara berimbang. Akan tetapi, dalam penerapannya, masih terdapat beberapa kelemahan yang dirasakan ketika proses pembelajaran berlangsung, di antaranya: pertama, proses pembelajaran masih didominasi oleh penguasaan pengetahuan daripada pembentukan sikap dan keterampilan sehingga dihasilkan siswa yang kaya akan pengetahuan, akan tetapi kurang memiliki sikap yang baik dan minim akan penguasaan keterampilan dalam 
mencipta sesuatu. Kedua, proses pembelajaran yang semula diamanatkan menerapkan pendekatan tematik mulai dari kelas I sampai kelas III SD, ternyata dalam pelaksanaannya masih menggunakan pendekatan mata pelajaran sehingga kurang mampu mengadopsi karakteristik siswa yang masih berpikir secara holistik.

Mengatasi masalah yang diungkapkan, pemerintah dalam hal ini Kemendikbud melakukan perbaikan mulai dari struktur kurikulum, penerapan proses pembelajaran, hingga penilaian pembelajaran. Dalam penerapannya, tidak sedikit kritik, masukan, maupun saran yang terlontar dari berbagai kalangan di masyarakat terutama dari kalangan akademisi, praktisi pendidikan, dan orang tua.

Walaupun demikian, perlu dipahami bahwa kritik, masukan, maupun saran hendaknya diterima dengan tangan terbuka dan pikiran positif sebagai upaya menciptakan efektivitas penerapan kurikulum 2013 di lapangan. Masukan yang diberikan hendaknya dijadikan refleksi uji kelayakan suatu kebijakan apakah dapat memberikan dampak positif yang signifikan atau tidak terutama dalam menciptakan siswa Indonesia yang cerdas, terampil, dan berakhlak mulia.

Paparan di atas mengisyaratkan bahwa lazimnya sebagai suatu kebijakan publik, implementasi kurikulum 2013 di SD perlu diiringi dengan suatu studi implementasi kebijakan untuk memantau jalannya kebijakan. Dari studi implementasi ini akan dapat diketahui keberhasilan dan kegagalan sebuah kebijakan, sehingga secara normatif akan diperoleh rekomendasi apakah kebijakan dapat dilakukan perlu perbaikan sebelum dilanjutkan, atau bahkan harus dihentikan. Studi implementasi kebijakan ini juga akan dapat menilai keterkaitan antara teori (kebijakan) dengan praktiknya (implementasi kebijakan). Dengan studi implementasi kebijakan ini dapat diketahui apakah hasil dan dampak kebijakan tersebut sesuai dengan yang diperkirakan atau tidak.

Dari hasil studi ini akan dapat dinilai apakah sebuah kebijakan/ program memberikan manfaat atau tidak bagi kelompok sasaran yang dituju. Secara normatif fungsi studi implementasi sangat dibutuhkan sebagai bentuk pertanggungjawaban publik, terlebih di mana masyarakat yang semakin kritis memonitor kebijakan pemerintah. Studi implementasi ini sekaligus sebagai upaya untuk menjalankan fungsi pengawasan/pengendalian bagi satu kebijakan.

\section{METODE PENELITIAN}

Jenis penelitian yang digunakan adalah metode deskriptif. Penelitian deskriptif (descriptive research) adalah penelitian yang dilakukan untuk mengetahui nilai variabel mandiri, baik satu variabel atau lebih (independent) tanpa membuat perbandingan, atau menghubungkan dengan variabel yang lain (Sugiyono, 2009:11). 
Selanjutnya, dijelaskan pula bahwa penelitian deskriptif adalah penelitian yang bertujuan untuk memperoleh deskripsi tentang ciri-ciri variabel (karakteristik responden dan pesan yang ingin disampaikan serta persepsi responden) (Spradley, 1997:74).

Jenis penelitian yang dilakukan adalah penelitian kebijakan yang memiliki ciri khusus adanya identifikasi berbagai isu atau permasalahan yang timbul terkait dengan pembuatan kebijakan dan setelah data diperoleh si peneliti melakukan analisis kebijakan berdasarkan data. Oleh sebab itu, penerapan kurikulum 2013 sebagai bagian dari kebijakan pemerintah yang dalam hal ini Kemendikbud, perlu ditinjau ulang efektivitas penerapannya di sekolah terutama tingkat SD, khususnya di kabupaten Pasaman Barat.

Tujuan pelaksanaan penelitian ini untuk mengetahui isuisu menonjol dalam implementasi kurikulum 2013 di SD. Sesuai dengan tujuan ini, yang akan diperoleh dari penelitian ini adalah data kuantitatif dan kualitatif dalam bentuk gambaran kesiapan, pelaksanaan proses pembelajaran, sistem evaluasi, dan keterpakaian buku guru dan buku siswa serta gambaran permasalahan lain yang muncul. Setelah permasalahan ditemukan, dilakukan studi pustaka atau studi literatur untuk menjawab permasalahan atau isu-isu menonjol yang ditemukan.
Sesuai dengan tujuan penelitian, sistematika penelitian dilakukan sebagai berikut.

a. Tahap pertama, mengkaji efektivitas pelaksanaan pembelajaran tematik terpadu dalam implementasi kurikulum 2013 di SD mulai dari perencanaan, pelaksanaan pembelajaran tematik terpadu, dan bentuk evaluasi. Hal ini dilakukan melalui pengamatan proses pembelajaran di kelas.

b. Tahap kedua, peneliti mengkaji permasalahan yang muncul dan faktor penyebabnya dalam implementasi kurikulum 2013 di SD sehingga diperoleh data otentik sesuai dengan kenyataan yang dialami responden di lapangan.

c. Tahap ketiga, peneliti melakukan studi pustaka atau studi literatur dalam upaya menjawab atau memberikan solusi terhadap permasalahan yang dihadapi para guru di lapangan.

Pengumpulan data dilakukan dengan menggunakan instrumen yang telah disediakan. Instrumen penilaian perencanaan, pelaksanaan proses pembelajaran, dan evaluasi hasil belajar, menggunakan instrumen yang telah disediakan dalam materi pendampingan kurikulum 2013 di SD. Selanjutnya, untuk wawancara dibuat instrumen wawancara berupa daftar pertanyaan sesuai dengan indikator yang ditetapkan. Data kuantitatif yang terkumpul diolah secara statistik, sementara data kualitatif dianalisis 
secara deskriptif. Selain itu, dilihat juga keterkaitan antara data kualitatif dan kuantitatif untuk memperoleh data otentik secara keseluruhan.

\section{HASIL PENELITIAN DAN PEMBAHASAN \\ Mekanisme Perbaikan Kurikulum 2013 di SD}

Pemerintah yang dalam hal ini Kemendikbud telah melakukan uji publik berkaitan dengan efektivitas penerapan kurikulum 2013 di lapangan. Hal ini dilakukan sebagai upaya memperoleh gambaran ataupun respon dari berbagai kalangan, baik dari praktisi pendidikan, akademisi, maupun orang tua. Respon ini kemudian dijadikan bahan masukan atau rujukan dalam penyempurnaan kurikulum 2013 di masa yang akan datang.

Kemendikbud menerapkan kurikulum 2013 secara bertahap dan terbatas. Bertahap maksudnya penerapan kurikulum 2013 tidak langsung diterapkan pada seluruh kelas, namun dimulai dari kelas I dan IV, kemudian dilanjutkan kelas II dan V, dan terakhir pada kelas III dan VI. Terbatas maksudnya, penerapan kurikulum 2013 terutama di SD hanya dilakukan pada sekolahsekolah piloting dalam jumlah terbatas di seluruh Indonesia (Permendikbud No.81A Tahun 2013). Hal ini dilakukan agar lebih mudah memantau tingkat efektivitas penerapannya dan perbaikan apa yang akan dilakukan pada proses selanjutnya demi kesempurnaan kurikulum 2013 ke depan.

Penerapan kurikulum 2013 di lapangan belum dikatakan berjalan mulus, masih banyak masukan dan saran dari praktisi pendidikan, akademisi, maupun orang tua siswa sendiri. Hal inilah yang dimaksud dengan masukan publik. Masukan publik berupa struktur kurikulum, buku guru dan buku siswa, hingga pada proses penilaian pembelajaran, baik pada aspek sikap, pengetahuan, maupun keterampilan. Kesemuanya itu tentu memberikan arahan agar pemerintah yang dalam hal ini Kemendikbud dianjurkan melakukan perbaikan, mulai dari struktur kurikulum, buku guru dan buku siswa, hingga pada penilaian pembelajaran.

Proses perbaikan kurikulum kemudian dilakukan secara terprogram yang disesuaikan dengan masukan publik. Perbaikan mulai dilakukan dari struktur kurikulum, buku guru dan buku siswa, hingga pada pedoman penilaian. Struktur kurikulum yang dilakukan perbaikan terutama pada susunan tingkat kesulitan materi (dari yang mudah kepada yang lebih sulit) dan tingkat kedalaman materi. Perbaikan struktur kurikulum berimbas pada perbaikan buku guru dan buku siswa. Hal ini karena pemetaan Kometensi Dasar (KD) atau pemetaan materi yang ada pada buku guru dan buku siswa sebelumnya sudah tidak sesuai lagi karena telah dilakukan perbaikan pada struktur kurikulum. Demikian juga pada penilaian pembelajaran. 
Buku pedoman penilaian kemudian diperbaiki, agar lebih efektif dan lebih mudah dipahami dan digunakan guru ketika melakukan penilaian dalam proses pembelajaran di kelas.

Tindak lanjut perbaikan pada aspek-aspek tertentu seperti yang telah dipaparkan di atas, dilakukan kembali uji publik. Uji publik ini dilakukan untuk mengetahui kelemahan dan kekurangan terhadap perbaikan yang telah dilakukan, baik dari segi struktur kurikulum, buku guru dan buku siswa, maupun penilaian. Dengan masukan ini diperoleh gambaran kurikulum yang lebih sempurna seperti apa yang dicita-citakan. Setelah dilakukan uji publik, dilakukan finalisasi kurikulum. Finalisasi kurikulum ini diharapkan dapat memberikan kontribusi yang lebih baik dalam penerapan selanjutnya walaupun masih secara bertahap dan skala terbatas.

\section{Isu-isu Menonjol dalam Evaluasi Kurikulum 2013 di SD}

Seperti apa yang telah dipaparkan sebelumnya, penerapan kurikulum 2013 di lapangan belum dikatakan berjalan mulus. Masih terdapat berbagai isu berupa kritik dan saran dari berbagai kalangan terkait dengan kekurangan kurikulum 2013 yang telah dilakukan di SD. Beberapa isu penting yang perlu menjadi pusat perhatian, khususnya di tingkat SD, antara lain:

1. Kebenaran Kompetensi Dasar (KD), mencakup: konsep/substansi, ruang lingkup (scope), urutan (sequence), penempatan pada Kompetensi Inti (KI), dan keterbacaan.

2. Kedudukan pada Kompetensi Inti Spritual (KI-1) dan Kompetensi Inti Sosial (KI-2).

3. Pembelajaran tematik terpadu SD/MI.

4. Penilaian sikap.

Isu-isu penting di atas perlu ditindak lanjuti, mengingat halhal inilah yang menjadi gejolak utama di lapangan. Untuk lebih jelasnya dapat dilihat pada jabaran berikut.

\section{Kebenaran Kompetensi Dasar (KD)}

Berdasarkan temuan di lapangan, masih terdapat berbagai kekurangan pada rumusan KD sebelumnya. Kekurangan itu dirasakan pada beberapa aspek, meliputi: konsep/substansi, ruang lingkup (scope), urutan (sequence), penempatan pada Kompetensi Inti (KI), dan keterbacaan. Pada kebenaran konsep/substansi, ditemukan beberapa istilah maupun pengertian yang kurang sesuai dengan konsep yang sebenarnya.

Ruang lingkup (scope) KD, dirasakan pendangkalan materi sehingga belum dapat mengadopsi seluruh pengetahuan yang seharusnya diberikan kepada siswa.

Urutan (sequence) belum tersusun secara sistematis dalam artian dari yang mudah kepada yang lebih sulit, dari yang sederhana kepada yang lebih kompleks. 
Penempatan

pada

Kompetensi Inti (KI), khusunya KI-3 dan KI-4 masih terdapat beberapa KD yang belum sesuai. Misalnya saja, pada KI-3 (pengetahuan) menuntut pengetahuan tertentu, namun pada KI-4 (keterampilan) belum menggambarkan tuntutan keterampilan sesuai dengan pengetahuan yang ada pada KI-3.

Dalam hal ini dikatakan bahwa KI-3 dan KI-4 belum berpasangan secara ajeg. Kemudian, pada aspek keterbacaan, masih dirasakan redaksi bahasa beberapa KD yang berbelit-belit dan terlalu panjang sehingga sulit dipahami oleh guru dalam menerapkan dan mengukur ketercapaiannya di lapangan.

Gambaran di atas memberikan arahan bahwa perlu dilakukan review dan revisi terhadap semua KD pada semua mata pelajaran berdasarkan kebenaran konsep/substansi, ruang lingkup (scope), urutan (sequence), penempatan pada Kompetensi Inti (KI), dan keterbacaan. Konsep/substansi perlu ditinjau ulang sesuai dengan konsep yang sebenarnya. Ruang lingkup perlu diperkaya sehingga tidak terjadi pendangkalan materi. Urutan (sequence) perlu disusun secara sistematis sehingga diperoleh gambaran penguasaan materi dari yang mudah kepada yang lebih sulit, dari yang sederhana kepada yang lebih kompleks. Penempatan pada KI-3 dan KI-4 perlu disinkronkan agar tuntutan pengetahuan sejalan dengan keterampilan yang harus dikuasai oleh siswa. Redaksi bahasa (keterbacaan) perlu disederhanakan dan diefektifkan sehingga lebih mudah dipahami oleh setiap pengguna di lapangan.

\section{Kedudukan pada KI-1 dan KI-2}

Masalah yang muncul di lapangan adalah adanya anggapan agamaisasi pada semua mata pelajaran, padahal sebenarnya tidak. Anggapan ini muncul karena kurang pahamnya guru terhadap cakupan dan muatan yang dituntut berdasarkan KI-1 (spritual) dan KI-2 (sosial). Rasional kebijakan munculnya KI-1 dan KI-2 sebenarnya mengacu pada tujuan pendidikan nasional dalam Undangundang Nomor 20 Tahun 2003 tentang sistem pendidikan nasional, yaitu: Berkembangnya potensi peserta didik agar menjadi manusia yang beriman dan bertaqwa kepada Tuhan yang Maha Esa, berakhlak mulia, sehat, berilmu, cakap, kreatif, mandiri, dan menjadi warga negara yang demokratis serta bertanggungjawab. Tujuan pendidikan nasional tersebut dirinci dan dikelompokkan pada masingmasing kompetensi, yaitu KI-1: Spritual; KI-2: Sosial; KI-3: Pengetahuan; dan KI-4: Keterampilan.

KI-1 dan KI-2 bukan menyeluruh menyeru pada "agamaisasi", namun perlu melihat cakupan kompetensi yang diinginkan, lebih-lebih pada KI-2 yaitu berakhlak mulia, sehat, 
mandiri, dan menjadi warga negara yang demokratis serta bertanggungjawab. Oleh sebab itu, seorang guru perlu melihat dan menyesuaikan dengan baik cakupan kompetensi yang ingin dicapai sesuai dengan muatan pada KI-1 dan KI-2.

Kurikulum

2013

mengarahkan pembelajaran dimulai dengan penanaman pengetahuan (KI3) terlebih dahulu, baru kemudian diberikan penguasaan keterampilan (KI-4). Selanjutnya, diarahkan pada pencapaian kompetensi spritual (KI1) dan sosial (KI-2) sebagai nurturant effect dari pembelajaran.

Kembali dijelaskan bahwa penguasaan KI-1 dan KI-2 sebagai nurturant effect pembelajaran bukan merupakan proses "agamaisasi", namun disesuaikan dengan tuntutan kompetensi yang ingin dicapai, misalnya: beriman dan bertaqwa kepada Tuhan YME, berakhlak mulia, sehat, mandiri, warga negara yang demokratis, dan bertanggung jawab.

Berdasarkan paparan di atas, Kemendikbud melakukan redesain penyusunan pada KI-1 dan KI-2, yaitu:

a. Untuk mata pelajaran Pendidikan Agama dan Budi Pekerti serta $P P K n, \mathrm{KD}-\mathrm{KD}$ pada KI-1, KI-2, KI-3., dan KI-4 koheren dan linier satu sama lain. Sebagai contoh dapat dilihat pada mata pelajaran Pendidikan Agama Islam dan Budi Pekerti.

b. Untuk mata pelajaran lainnya, KD-KD pada KI-3 dan KI-4 koheren dan linier satu sama lain; demikian pula KD pada KI-1 dan KI-2 koheren dan linier. Kemudian ada pula KD pada KI3 dan KI-4 koheren tapi tidak linier dengan KD pada KI-1 dan KI-2. KD pada KI-1 dan KI-2 bersifat akumulatif untuk satu tahun.

Implikasi dari redesain yang dilakukan ini berujung pada perubahan Permendikbud Nomor 57, 58, 59, dan 60 Tahun 2014 tentang Kurikulum 2013 pada bagian KD dan silabus serta bagian terkait lainnya (Kabalitbang, 2015).

\section{Pembelajaran Tematik Terpadu SD/MI}

Teori Gestalt menjelaskan bahwa perkembangan usia dan perkembangan kognitif siswa SD/MI menganjurkan bahwa proses pembelajaran hendaknya dimulai dengan besaran ke rincian, dari keseluruhan/keutuhan (holistic) ke bagian-bagian. Oleh karena itu, pembelajaran di SD/MI menggunakan tema sebagai stimulasi besaran/keutuhan menuju pemahaman detail. Dalam hal ini tema digunakan sebagai kendaraan dalam memahami KD setiap mata pelajaran. Pembelajaran yang demikian dinamakan dengan pembelajaran tematik terpadu.

Pendekatan tematik terpadu memungkinkan siswa untuk belajar melalui pendekatan lingkungan, meluas mulai dari diri, keluarga, lingkungan, dan seterusnya. Melalui tema, siswa memperoleh pengalaman belajar secara autentik melalui 
kehidupan nyata di lingkungannya (Permendikbud Nomor 103 Tahun 2014).

Ketika uji publik tahun 2012 (sebelum disahkan oleh Mendikbud) ditawarkan 3 (tiga) pilihan yaitu tematik-terpadu kelas I-III, I-IV, dan I-VI. Ternyata sebagian besar merekomendasikan tematik-terpadu dilakukan pada kelas I-VI, dengan melihat karakteristik siswa SD/MI secara menyeluruh. Berdasarkan rekomendasi tersebut dibuatlah buku teks siswa dan buku guru secara nasional. Berdasarkan pengalaman sebelumnya (Kurikulum 2006/KTSP), kalau tidak dibuatkan buku ternyata pembelajaran berlangsung dengan pendekatan mata pelajaran, bukan pendekatan tematik terpadu. Padahal pada Kurikulum 2006 mengamanatkan pendekatan tematik terpadu pada kelas I sampai kelas III SD/MI.

Berdasarkan temuan di lapangan, ditemukan beberapa masalah tentang penerapan pembelajaran tematik terpadu di SD/MI, antara lain:

a. Melemahkan penguasaan substansi mata pelajaran yang bersumber dari disiplin ilmu (terjadi pendangkalan materi).

b. Pemetaan KD dari beberapa mata pelajaran pada silabus maupun pada buku teks tidak berurutan dan tidak proporsional sehingga guru sulit memahami keutuhan materi.

c. Tema yang dibuat sama secara nasional dirasakan kurang relevan dengan keberagaman daerah di wilayah NKRI.

(Dilemanya: belum semua daerah/guru mampu menyusun tema sesuai dengan kondisi daerah dan kondisi kekinian).

d. Dalam penulisan buku tematik terpadu, guru mengalami kesulitan dalam memetakan KD secara berurutan dan proporsional yang bersumber dari beberapa mata pelajaran.

Implikasi dari gambaran di atas, perlu disusun dan disempurnakan kembali silabus berbasis mata pelajaran dan silabus tematik terpadu. Hal ini dilakukan agar guru memahami keluasan dan kedalaman dari setiap mata pelajaran. Bagi daerah/ sekolah/ guru yang mampu, dapat mengembangkan tema sesuai dengan kondisi daerah dan kondisi kekinian yang mengacu pada silabus mata pelajaran.

Penyempurnaan silabus tematik terpadu disusun sesuai urutan dan ruang lingkup KD. Selanjutnya, dilakukan perbaikan buku guru dan buku siswa berdasarkan hasil penyempurnaan silabus. Namun, perlu dijelaskan bahwa buku bukanlah satu-satunya sumber belajar bagi siswa. Buku dapat disempurnakan dan dikembangkan atau dijadikan sebagai contoh sesuai dengan kebutuhan dan kekinian. Daerah/ sekolah/ guru yang mengembangkan sendiri sesuai dengan kondisi daerah dan kondisi kekinian hendaknya mengacu pada silabus berbasis mata pelajaran dan tematik terpadu yang telah disusun. 
Kemendikbud menegaskan di setiap halaman depan buku guru dan buku siswa dengan pernyataan "Disklaimer" tentang penggunaan buku guru dan siswa dalam pembelajaran. Berikut ini pernyataan Kemendikbud dalam "disklaimer"nya: "Buku ini merupakan buku yang dipersiapkan pemerintah dalam rangka implementasi kurikulum 2013. Buku guru dan buku siswa ini disusun dan ditelaah oleh berbagai pihak di bawah koordinasi Kementerian Pendidikan dan Kebudayaan, dan dipergunakan dalam tahap awal penerapan kurikulum 2013. Buku ini merupakan "dokumen hidup” yang senantiasa diperbaiki, diperbaharui, dan dimutakhirkan sesuai dengan dinamika kebutuhan dan perubahan zaman. Masukan dari berbagai kalangan diharapkan dapat meningkatkan kualitas buku ini" (Kemendikbud, 2013a:14).

Berdasarkan pernyataan di atas, guru hendaknya tidak sepenuhnya hanya menggunakan satu buku sumber saja dalam pembelajaran, akan tetapi hendaknya menggunakan sumber yang lebih bervariasi atau mengembangkannya. Kalaupun hanya menggunakan buku sumber yang diterbitkan oleh Kemendikbud (2013a:15), guru hendaknya lebih mengembangkan materi yang ada pada buku tersebut mengingat bahwa materi yang ada pada buku, baru dalam tahap standar minimal. Oleh sebab itu, kepiawaian guru dalam mengembangkan materi pembelajaran mutlak diperlukan dalam rangka menciptakan proses pembelajaran yang sesuai dengan tuntutan kurikulum 2013 dan memaksimalkan proses pembelajaran secara optimal.

\section{Penilaian}

Pemahaman tentang penilaian telah dijelaskan bahwa pendidikan hendaknya tidak hanya mengembangkan pengetahuan semata-mata, tetapi juga harus mengembangkan keterampilan dan sikap secara holistik. Oleh karena itu, ketiga aspek tersebut harus dikembangkan dalam pembelajaran, dinilai, dan ditagih dalam rapor.

Berdasarkan pengalaman kurikulum sebelumnya, kalau tidak ditagih dalam rapor, guru malas mengembangkan dan mengimplementasikannya.

Pencantuman nilai dalam rapor sesuai dengan rumusan SKL, KI, dan KD meliputi sikap, pengetahuan, dan keterampilan.

Permasalahan yang muncul di lapangan ditemukan bahwa guru merasa repot, rumit, dan tidak cukup waktu untuk melaksanakan penilaian sikap. Oleh sebab itu, perlu dilakukan usaha perbaikan mengatasi hal itu berupa penyederhanaan penilaian pada hal-hal berikut.

a. KI-3 dan KI-4 dengan skala 1100, dengan ketuntasan belajar minimal 60. Namun, sekolah boleh menetapkan di atasnya.

b. KI-1 dan KI-2 dengan predikat Sangat Baik/A, Baik/B, Cukup/C, Kurang/D. Nilai rapor ditetapkan oleh wali kelas 
dengan ketuntasan belajar minimal B (Kemendikbud, 2013b).

Implikasi dari permasalah yang ditemukan, dilakukan penyusunan pedoman penilaian sikap yang lebih sederhana dan operasional. Selanjutnya, menyempurnakan Permendikbud No. 104 Tahun 2014 tentang penilaian hasil belajar (Kabalitbang, 2015).

\section{KESIMPULAN}

Berdasarkan temuan di lapangan, masih terdapat berbagai isu berupa kritik dan saran positif terkait dengan kekurangan kurikulum 2013 yang telah dimplementasikan di SD, khususnya di Kab. Pasaman Barat. Beberapa isu penting yang perlu menjadi pusat perhatian, di antaranya: (1) Kebenaran Kompetensi Dasar (KD), mencakup: konsep/substansi, ruang lingkup (scope), urutan (sequence), penempatan pada Kompetensi Inti (KI), dan keterbacaan, Kedudukan pada Kompetensi Inti Spritual (KI-1) dan Kompetensi Inti Sosial (KI-2), (3) Pembelajaran tematik terpadu SD/MI, dan (4) Penilaian sikap. Isu-isu penting tersebut perlu diberikan tindak lanjut dan perbaikan untuk meningkatkan efektivitas implementasi kurikulum 2013, khususnya jenjang SD.

\section{DAFTAR RUJUKAN}

Kabalitbang. 2015. Perkembangan Perbaikan Kurikulum 2013. Makalah disajikan dalam Seminar Perbaikan
Kurikulum 2013 Jenjang

Pendidikan Dasar, Puskurbuk

Kemendikbud, Jakarta, 06

Juni 2015.

Kemendikbud. 2013a. Materi

Pelatihan Implementasi

Kurikulum 2013. Jakarta:

Badan Pengembangan

Sumber Daya Manusia dan

Kebudayaan dan Penjaminan

Mutu Pendidikan.

Kemendikbud.

------. 2013b. Panduan Teknis

Penilaian di Sekolah Dasar.

Jakarta: Kemendikbud.

Dirjen Pendidikan Dasar.

Peraturan Menteri Pendidikan dan

Kebudayaan Republik

Indonesia Nomor 81A Tahun

2013 tentang Implementasi

Kurikulum. Jakarta:

Kemendikbud.

Peraturan Menteri Pendidikan dan

Kebudayaan Republik

Indonesia Nomor 103 Tahun

2014 tentang Pembelajaran

pada Pendidikan Dasar dan

Pendidikan Menengah.

Jakarta: Kemendikbud.

Peraturan Menteri Pendidikan dan

Kebudayaan Republik

Indonesia Nomor 104 Tahun

2014 tentang Penilaian Hasil

Belajar oleh Pendidik pada

Pendidikan Dasar dan

Pendidikan Menengah.

Jakarta: Kemendikbud.

Spradley, James P. 1997. Metode

Etnografi. Terjemahan oleh

Misbah Zulfa Elizabeth.

Yokyakarta: Tiara Wacana. 
Sugiyono. 2009. Metode Penelitian

\section{Pendidikan Pendekatan}

Kuantitatif, Kualitatif, dan

$R \& D$. Bandung: Alfabeta.

Undang-undang Nomor 20 Tahun

2003 tentang Sistem

Pendidikan Nasional. 